\title{
Subsidence resulting from the dissolution of Permian gypsum in the Ripon area; its relevance to mining and water abstraction
}

\section{A. H. Cooper}

Published in BELL, F. G., CULSHAW, M. G., CRIPPS, J. C. \& LOVELL, M. A. (eds) 1988. Engineering Geology of Underground Movements, Geological Society Engineering Geology Special Publication No. 5, pp. 387-390.

ABSTRACT: Because gypsum dissolves rapidly in flowing water the subsurface dissolution of Permian gypsum at Ripon results in severe subsidence. The pattern of subsidence and methods of propagation are similar to those which might result from mining. Breccia pipe propagation and bulking factors for Permian rocks are discussed. The implications both of gypsum dissolution and the forceful expansion of anhydrite by hydration in flooded gypsum mines are assessed. The removal of gypsum and possible subsidence caused by large-scale water abstraction and mine dewatering are also considered.

\section{Introduction}

Until recently strata containing gypsum were not considered to be a serious geological hazard. Gypsum dissolves rapidly, however, especially in flowing water. Sub- surface dissolution can result in natural gypsum cave systems, with progressive cavern collapse, such as those developed at Ripon, North Yorkshire (Cooper 1986). The mechanisms operating in this situation are similar to those which may occur in abandoned gypsum mines or possibly be induced by either water abstraction or mine pumping. The natural subsidence phenomenon serves as a model and perhaps a warning of catastrophic subsurface processes which may be triggered off by man.

\section{The dissolution of gypsum}

Gypsum dissolves in flowing water about one hundred times more rapidly than limestone, but at only about one thousandth the rate of halite. At Ripon Parks (Fig. 1) where Permian gypsum abuts the River Urea large block $(3 \mathrm{~m} \mathrm{3}$ ) of gypsum fell into the river and dissolved in 14 months. This occurrence was reported by James et al. (1981) who presented formulae from which the gypsum dissolution rates can be calculated. The rate of gypsum dissolution increases with temperature and the speed at which water passes the gypsum surface. The gypsum dissolution rates observed in the field agreed closely with those obtained from laboratory experiments by James \& Lupton (1978) and by Kemper et al. (1975). These observations considered the dissolution of gypsum by pure water. In subsurface conditions where calcium carbonate is dissolved in the groundwater the solubility of gypsum is increased; gypsum solubility may also be increased by the presence of other ions in solution such as chloride (Kempe 1972).

Further evidence for natural gypsum dissolution is the marked subsidence which periodically affects the city of Ripon and its environs. The subsidence varies from slight sags to catastrophic collapses of areas up to $30 \mathrm{~m}$ in diameter and up to $20 \mathrm{~m}$ deep. About 40 instances of catastrophic subsidence were reported by Cooper (1986) in the Ripon area. Two gypsum units occur at Ripon associated with dolomitic limestones and calcareous mudstones (Fig. 1). The strata are Permian in age and are overlain by the Triassic Sherwood Sandstone Group (Fig. 1) (Smith et al. 1986). Up to 30 m of gypsum occurs in the Edlington Formation (formerly called Middle Marls) and up to $10 \mathrm{~m}$ of gypsum in the Roxby Formation (formerly Upper Marls). The limestones are the Cadeby Formation (formerly Lower Magnesian Limestone) and the Brotherton Formation (formerly Upper Magnesian Limestone); both are good aquifers, as is the Triassic Sherwood Sandstone Group. 


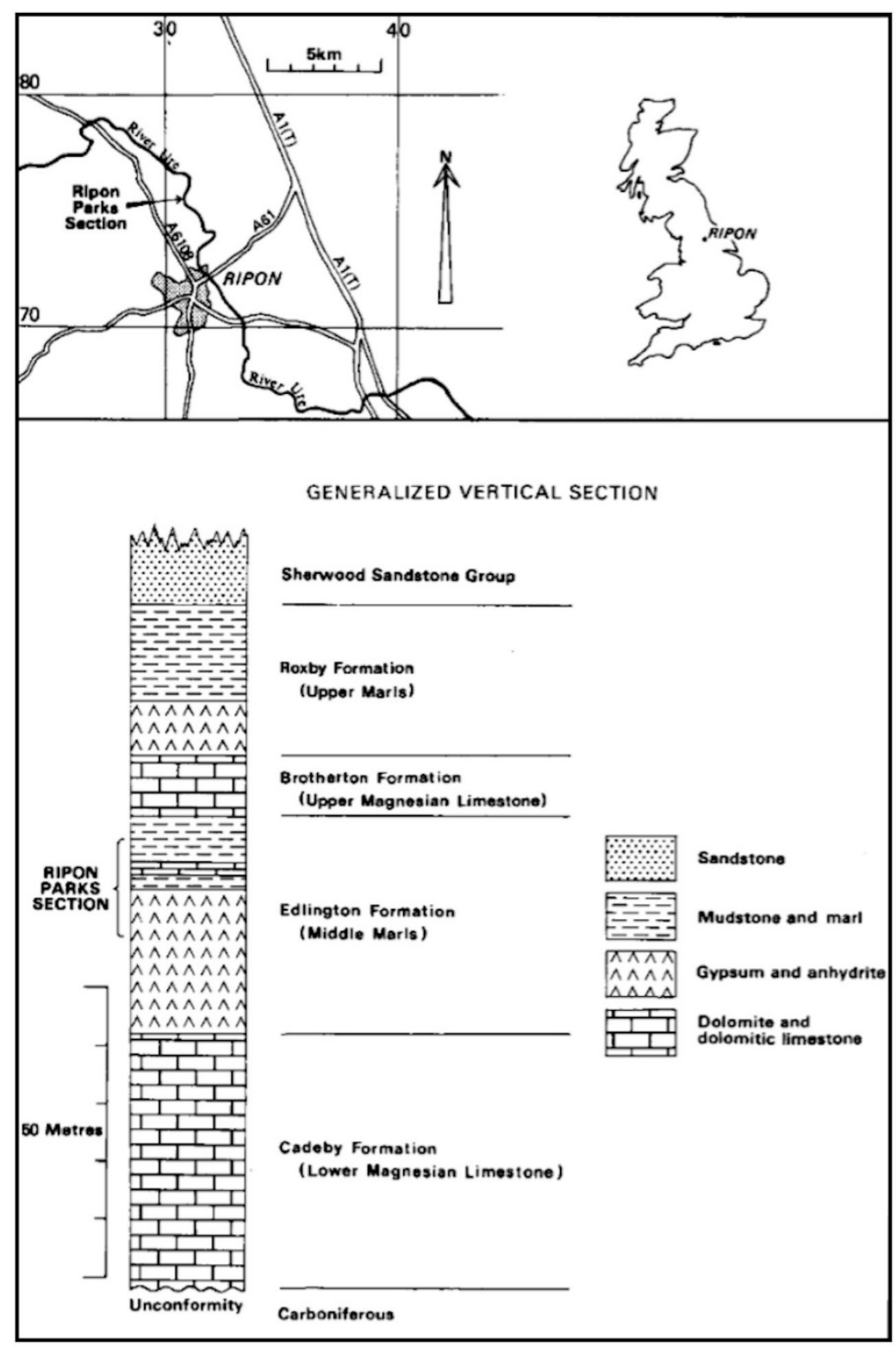

FIG. 1. Location map and generalized vertical section.

Around Ripon, water passes through the limestone aquifers and gypsum beds down dip eastwards to a partly gravel filled buried valley along the course of the River Ure. Water also passes down through the Sherwood Sandstone then laterally westwards across the dip into the Permian sequence before emerging in the buried valley. This phreatic passage of water through and adjacent to the gypsum beds causes them to dissolve. The dissolution occurs preferentially along the joints as in limestone cave systems. The most rapid dissolution occurs at the joint intersections where caverns develop, enlarge and possibly amalgamate. Eventually the overlying rock cannot span the space and subsidence is initiated. The result is subsidence hollows at the surface; these form a grid-like pattern which Cooper (1986) related to joint directions. The subsidence pattern is comparable with, but more random than, that produced over shallow pillar and stall workings (Piggott \& Eynon 1978, Lee \& Nichols 1981). The mechanisms involved in the natural subsidence are similar to those which could occur in abandoned flooded gypsum mines. 


\section{Subsidence and breccia pipe propagation}

Natural outcrops around Ripon poorly expose a few cross-sections through subsidence hollows and their associated breccia pipes. Similar breccia pipes are moderately exposed in the Sherburn in Elmet area of York- shire, but well exposed along the Durham coast (Smith 1972). At Ripon, numerous confidential site investigation boreholes give further information about the breccia pipes and subsidence areas. These boreholes and exposures show that when the gypsum beds dissolve, and collapse of the overlying strata is initiated, the main mode of failure is piecemeal caving. This results in breccia pipes that migrate upwards towards the surface. The pipes are similar to those developed over shallow coal workings and have similar geometries and characteristics to those described by Piggott \& Eynon (1978). As the cavity moves upwards the various rock types are affected in different ways by the collapse and brecciation.

The soft calcareous mudstones of the Edlington and Roxby formations (formerly Middle and Upper Marls) collapse easily and increase in volume both by brecciation and the expansive hydration of the clay. This gives a marked increase in volume, but the wet collapsed mudstones readily compact removing most of the open spaces from the collapsed breccia. This means that the mudstone lithologies effectively have a low bulking factor (sensu Piggott \& Eynon 1978) and contribute little to the choking of the upward migrating cavity. Further- more, the soft collapsed mudstones are readily eroded by the flowing water that dissolved the gypsum into whose space the), have fallen. Mud flow away from the base of the subsidence may occur into the surrounding caverns removing support from the base of the breccia pipes. Thus it can be seen that the mudstone lithologies may contribute little to the choking of the breccia pipes and may even induce more pronounced subsidence by erosion and flow. These observations are confirmed by the borehole data which generally show a much thinner sequence of mudstone in the collapsed areas than the unaffected areas.

In contrast the Brotherton Formation (formerly the Upper Magnesian Limestone) is a thin bedded hard porcellanous dolomitic limestone. When it collapses in a piecemeal way it has a high bulking factor and forms a breccia with an open structure similar to those illustrated by Smith (1972) from the Durham coast. Boreholes indicate that it can increase in volume by $40-60 \%$. In a few places, however, the limestone appears to have initially spanned the cavity and failed as a coherent plug. This probably happened in 1939 at Hall Garth Ponds, near Nunwick, north of Ripon (SE 3184 7472) where a hole about $30 \mathrm{~m}$ in diameter and $10 \mathrm{~m}$ deep appeared in solid limestone (Cooper 1986). If this mode of failure occurs the bulking factor may be small or negligible.

The Sherwood Sandstone Group is less competent than the Brotherton Formation. Boreholes and natural exposures of the collapsed sandstone indicate only a moderate amount of space around the fragments. Secondary compaction and weathering of the fragments also occurs in places degrading them to a soft sand. Upon collapse by brecciation the Sherwood Sandstone increases in volume by between $10-30 \%$. The sandstone may also fail as a plug, a mechanism which appears to have occurred in 1834 at Ripon railway station (SE 3186 7260) (Cooper 1986). Here a hole $11 \mathrm{~m}$ in diameter and $20 \mathrm{~m}$ deep opened up suddenly. Red sandstone occurs in the sides of the hole, the upper 6-8 $\mathrm{m}$ of which are overhanging.

From these observations it would appear that only the Brotherton Formation and the Sherwood Sandstone are competent enough to have an effective bulking factor, and then only if they fail in a piecemeal way. Around Ripon the maximum gypsum thickness totals $40 \mathrm{~m}$ in the two horizons. Associated with this gypsum there are two calcareous mudstone sequences each approximately 12 to $15 \mathrm{~m}$ thick. The maximum amount of strata dissolved or eroded could thus reach around $60 \mathrm{~m}$. If only the gypsum dissolved away, using the bulking factors mentioned above, and assuming rectangular collapse (Piggott \& Eynon 1978), $40 \mathrm{~m}$ of cavity could propagate upwards through at least $140 \mathrm{~m}$ of strata, and possibly up to $350 \mathrm{~m}$ of strata, before becoming choked. If conical collapse (sensu Piggott \& Eynon 1978), or failure of a 
crown hole, were to occur even greater figures could be possible. Around Ripon the subsidence belt width is not limited by propagation figures, but by the down-dip transition from gypsum to anhydrite. This is controlled by circulating ground water hydrating the anhydrite to gypsum, a transition which occurs at about $100 \mathrm{~m}$ depth (Cooper 1986). As a consequence of this, and the low bulking factors, considerable subsidence hollows appear at the surfaces even at the eastern limit of the subsidence belt.

\section{Gypsum mining}

The natural processes described above are of direct relevance to gypsum mining. Because gypsum dissolves readily in flowing water any gypsum mine which becomes flooded on abandonment should be subject to a hydrological study. If there is a water flow through the mine, then, from knowledge of that rate, the amount of potential dissolution can be calculated. Even if a mine is only partially flooded localized rapid flow of water around pillars at floor level could seriously under- cut them inducing their failure. Complete flooding of a mine would be unlikely to produce sufficient water flow to rapidly degrade the pillars, but any flow of water could slowly dissolve them. Failure of pillars by the washing out of any mudstone laminae is a further complication. Another mechanism that could also operate in a flooded gypsum mine is the reaction of water with any anhydrite in the gypsum sequence. As anhydrite hydrates to gypsum it undergoes a forceful expansion of up to $60 \%$ (Mossop \& Shearman 1973). This creates extreme pressures and has been responsible for rock explosions and local uplifts in America (Brune 1965). If this were to occur to a thin anhydrite bed exposed in a pillar within a flooded gypsum mine the forceful hydration might blow a piece from the pillar and weaken it. If this happened repeatedly the pillar could become degraded and fail resulting in subsidence. Failure of a mine roof over a stall, or collapse of a pillar could initiate upwardly migrating breccia pipes, or the collapse of an overlying plug of rock. In PermoTriassic strata the mechanisms of collapse and bulking factors of the sediments would probably be similar to those recorded for the natural subsidence in the Ripon area.

\section{Water abstraction}

Water abstraction from gypsum sequences or sequences in hydrological continuity could affect either natural gypsum-water systems or flooded mine workings. The Permian sequence is popular as an aquifer yielding considerable amounts of water for public and commercial use. The water is hard and commonly high in the amount of dissolved calcium sulphate and calcium carbonate. This water is popular with the brewing industry as it is naturally 'Burtonised'.

Calculations for a major water abstractor pumping from the Permian gypsum and limestone beds in Northern England show some alarming results. The water contains approximately 1200 ppm of SO4 mainly as dissolved CaSO4; the abstractor pumps $212 \mathrm{M} 1$ of water per annum. This is equivalent to removing approximately $200 \mathrm{~m} 3$ of gypsum a year from the area. It is likely that much of the dissolution represents the enlargement of joints over a wide area. However, adjacent to the boreholes where rapid water flow occurs severe dissolution of the gypsum beds could occur and result in subsidence around the wellsite. Large scale pumping from coal mines beneath the Permian sequence could also increase the amount of gypsum dissolution. Originally still-standing areas of groundwater saturated in sulphates could be induced to flow by pumping thus allowing aggressive re-charge water to dissolve the gypsum beds. As with water abstraction the dissolution would probably occur over a large area, but if preferential lines of water flow were initiated (perhaps along major joints) a potential subsidence situation could be induced.

ACKNOWLEDGEMENTS: Thanks are due to M. Joyce, Dr J. Aldrick and Dr W. M. Edmunds for useful discussion. This paper is published with the permission of the Director, British Geological Survey, Natural Environment Research Council. 


\section{References}

BRUNE, G. 1965. Anhydrite and gypsum problems in Engineering geology. Engineering Geology (Sacramento), 2, 26-33.

COOPER, A. H. 1986. Subsidence and foundering of strata caused by the dissolution of Permian gypsum in the Ripon and Bedale areas, North Yorkshire. In: HARWOOD, G. M. SMITH, D. B. (eds) The English Zechstein and Related Topics, Geological Society Special Publication 22,127-39.

JAMES, A. N. \& LUPTON, A. R. R. 1978. Gypsum and anhydrite in foundations of hydraulic structures. Geotechnique, 28, 249-72.

JAMES, A.N., COOPER, A. H. \& HOLLIDAY, D. W. 1981. Solution of the gypsum cliff (Permian, Middle Marl) by the River Ure at Ripon Parks, North Yorkshire. Proceedings of the York shire Geological Society, 43, 44350. KEMPE, S. 1972. Cave genesis in gypsum with particular reference to underwater conditions, Cave Science. Journal of the British Spelaeological Association, 49, 1-6.

KEMPER W. D., OLSEN, J. \& DE MOOY, C. J. 1975. Dissolution rate of gypsum in flowing water. Proceedings of the Soil Science Society of America, 39, 458-63.

LEE, S. \& NICHOLS, D. R. 1981. Subsidence. In: HAYS, W. W. (ed.) Facing Geologic and Hydrologic Hazards, Earth Science Considerations. U.S. Geological Survey Professional Paper 1240-B, 73-83.

MOSSOP, G. D. \& SHEARMAN, D. J. 1973. Origins of secondary gypsum. Transactions of the Institute of Mining and Metallurgy, 82, B147-54.

PIGGOTT, R. J. \& EYNON, P. 1978. Ground movements arising from the presence of shallow abandoned mine workings. In: GEDDES, J. D. (ed.) Proceedings of the First Conference on Large Ground Movements and Structures, Cardiff, 1977. Pentech Press, London, 749-80.

Smith, D. B. 1972. Foundered strata, collapse breccias and subsidence features of the English Zechstein. In: RICHTER- BERNBURG, G. (ed.) Geology of Saline Deposits. Proceedings of the Hannover Symposium, (Earth Sciences 7), 255-69, Unesco, Paris.

SMITH, D. B., HARWOOD, G. M., PATTISON, J. \& PETTIGREW, T. H. 1986. A revised nomenclature for Upper Permian strata in eastern England. In: HARWOOD, G. M. \& SN1TH, D. B. (eds) The English Zechstein and related Topics, Geological Society Special Publication 22, 9-17. 